\title{
Identification of candidate reference genes for qRT-PCR normalization studies of salinity stress and injury in Onchidium reevesii
}

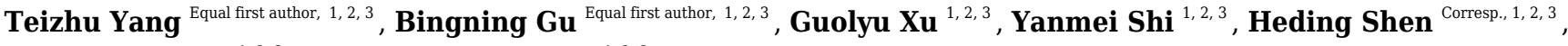 \\ Rongcheng Rao ${ }^{1,2,3}$, Hellen Lucas Mzuka ${ }^{1,2,3}$ \\ ${ }^{1}$ National Demonstration Center for Experimental Fisheries Science Education, Shanghai, China \\ 2 Key Laboratory of Exploration and Utilization of Aquatic Genetic Resources (Shanghai Ocean University), Ministry of Education, Shanghai, China \\ 3 Shanghai Universities Key Laboratory of Marine Animal Taxonomy and Evolution, Shanghai, China \\ Corresponding Author: Heding Shen \\ Email address: hdshen@shou.edu.cn
}

Real-time quantitative reverse transcription-PCR (qRT-PCR) is an undeniably effective tool for measuring levels of gene expression, but the accuracy and reliability of the statistical data obtained depend mainly on the basal expression of selected housekeeping genes in many samples. To date, there have been few analyses of stable housekeeping genes in Onchidium reevesii under salinity stress and injury. In this study, the gene expression stabilities of seven commonly used housekeeping genes, CYC, RPL28S, ACTB, TUBB, EF1a, Ubiq and $18 S$ RNA, were investigated using BestKeeper, geNorm, NormFinder and RefFinfer. Although the results of the four programs varied to some extent, in general, RPL28S, TUBB, ACTB and EFla were ranked highly. ACTB and TUBB were found to be the most stable housekeeping genes under salinity stress, and EFIa plus TUBB was the most stable combination under injury stress. When analysing target gene expression in different tissues, RPL28S or EF1a should be selected as the reference gene according to the level of target gene expression. Under extreme environmental stress (salinity) conditions, ACTB ( 0 ppt, 5 ppt, 15 ppt, 25 ppt) and TUBB (35 ppt) are reasonable reference gene choices when expression stability and abundance are considered. Under conditions of 15 ppt salinity and injury stress, our results showed that the best two-gene combination was TUBB plus EFIa. Therefore, we suggest that RPL28S, ACTB and TUBB are suitable reference genes for evaluating mRNA transcript levels. Based on candidate gene expression analysis, the tolerance of $O$. reevesii to low salinity (low osmotic pressure) is reduced compared to its tolerance to high salinity (high osmotic pressure). These findings will help researchers obtain accurate results in future quantitative gene expression analyses of $O$. reevesii under other stress conditions. 


\section{Identification of candidate reference genes for $q R T-P C R$}

2 normalization studies of salinity stress and injury in

3 Onchidium reevesii

4 Tiezhu Yang ${ }^{\llbracket 1,2,3}$, Bingning $\mathbf{G u}^{\llbracket 1,2,3}$, Guolyu $\mathbf{X u}^{1,2,3}$, Yanmei $\mathbf{s h i}^{1,2,3}$, Heding

5 Shen ${ }^{* 1,2,3}$,Rongcheng Rao ${ }^{1,2,3}$, Hellen Lucas Mzuka ${ }^{1,2,3}$

61 National Demonstration Center for Experimental Fisheries Science Education

72 Key Laboratory of Exploration and Utilization of Aquatic Genetic Resources (Shanghai Ocean University),

8 Ministry of Education, Shanghai, China

93 Shanghai Universities Key Laboratory of Marine Animal Taxonomy and Evolution, Shanghai, China.

10 I These authors are co-first authors and contributed equally to this work

$11 *$ hdshen@shou.edu.cn

\section{Abstract}

Real-time quantitative reverse transcription-PCR (qRT-PCR) is an undeniably effective tool for measuring levels of gene expression, but the accuracy and reliability of the statistical data obtained depend mainly on the basal expression of selected housekeeping genes in many samples. To date, there have been few analyses of stable housekeeping genes in Onchidium reevesii under salinity stress and injury. In this study, the gene expression stabilities of seven commonly used housekeeping genes, CYC, RPL28S, ACTB, TUBB, EF1a, Ubiq and $18 S$ $R N A$, were investigated using BestKeeper, geNorm, NormFinder and RefFinfer. Although the results of the four programs varied to some extent, in general, RPL28S, TUBB, ACTB and EFla were ranked highly. ACTB and $T U B B$ were found to be the most stable housekeeping genes under salinity stress, and $E F 1$ a plus $T U B B$ was the most stable combination under injury stress. When analysing target gene expression in different tissues, RPL28S or EFla should be selected as the reference gene according to the level of target gene expression. Under extreme environmental stress (salinity) conditions, $A C T B$ ( 0 ppt, 5 ppt, 15 ppt, $25 \mathrm{ppt}$ ) and TUBB (35 ppt) are reasonable reference gene choices when expression stability and abundance are considered. Under conditions of $15 \mathrm{ppt}$ salinity and injury stress, our results showed that the best two-gene combination was TUBB plus EF1a. Therefore, we suggest that RPL28S, $A C T B$ and $T U B B$ are suitable reference genes for evaluating mRNA transcript levels. Based on candidate gene expression analysis, the tolerance of $O$. reevesii to low salinity (low osmotic pressure) is reduced compared to its tolerance to high salinity (high osmotic pressure). These findings will help researchers obtain accurate results in future quantitative gene expression analyses of $O$. reevesii under other stress conditions.

\section{Introduction}

With advantages of relatively accurate quantification, high sensitivity and high throughput, quantitative reverse transcription polymerase chain reaction (qRT-PCR) has become one of the most widely used techniques to detect changes in gene expression ${ }^{1,2}$. Indeed, the use of qRT-PCR has increased tremendously in nearly all branches of biology $y^{3-6}$. However, there are inevitably a number of influencing factors that affect the efficiency 
of the reaction ${ }^{7}$, such as discrepancy in pipetting, the RNA quality and concentration, the efficiency of reverse transcription and amplification among different samples, the PCR procedures and primer amplification efficiency. Therefore, to avoid variations or errors, it is fundamental to standardize the level of target gene expression by utilizing in parallel a reference gene as an internal control ${ }^{8}$. In general, an ideal reference gene should demonstrate a consistent level of expression across all tested tissues or conditions ${ }^{9}$. Nonetheless, there is increasing evidence that expression of assumed reference genes can vary observably with experimental conditions such as developmental stage and chemical treatment, significantly affecting relative quantification and $\mathrm{qPCR}$ result interpretation.

Certain housekeeping genes, such as $18 S$ ribosomal RNA (18SrRNA), 28S ribosomal RNA (28SrRNA), $\beta$ actin (ACTB), cyclophilin (CYP2), elongation factor 1-alpha (EF1a), glyceraldehyde-3-phosphate dehydrogenase (GAPDH), translation elongation factor (TEF), tubulin (TUBB) and polyubiquitin $(U B Q)^{10-12}$, are commonly used as reference genes. As these housekeeping genes are related to basic metabolic processes and are essential for normal cell growth, their expression levels are thought to be stable. However, many recent studies have revealed that fluctuations in the expression levels of housekeeping genes may be largely influenced by the tissue, individual developmental stage or experimental conditions ${ }^{13}$. In fact, there is no clear evidence to show that a single universal reference gene is suitable for different tissues and varying experimental conditions ${ }^{14}$. Thus, it is crucial to determine one or two stably expressed reference genes before they are applied for normalizing the expression levels of target genes based on qRT-PCR.

Onchidium reevesii (Mollusca, Gastropoda, Pulmonata, Systellommatophora, Onchidiidae) is a brackish water amphibious sea slug that resides mainly in river ports of the intertidal zone and coastal tidal flats, reed and mangroves ecosystems ${ }^{15,16}$. The species is rich in natural collagen, which has high nutritional and medicinal value; thus, it may constitute an excellent specialty aquatic product for humans if issues pertaining to their breeding in captivity can be resolved ${ }^{17}$. Moreover, $O$. reevesii is an important part of the biodiversity of wetlands and is considered to be a model organisms for studying the evolution of marine invertebrates from sea to land ${ }^{18}$. $O$. reevesii has been investigated with regard to morphological, physiological and active substance aspects, and further molecular biology research is urgent ${ }^{19-21}$. Additionally, suitable reference genes are important for accurately interpreting expression analyses of functional genes and for evaluating RNAi efficiency. O. reevesii is a euryhaline organism, and the salinity of its habitat varies greatly under the influence of tides, rainfall, river flow and other factors. Due to its complex geographical environment and biodiversity, these organisms are inevitably attacked and injured by natural enemies. In this study, an extreme environment (salinity) and stress conditions were imposed on $O$. reevesii in an effort to determine stably expressed internal reference genes under such treatment and to provide basic data for future studies on its ability to regulate osmotic pressure, to adapt to extreme environments and to repair damage.

\section{Materials and methods}

\section{Animals and treatments}

Shanghai Ocean University of Leicester granted Ethical approval to carry out the study within its facilities (Approval number: Shou-DW-2019-010). Sexually mature O. reevesii adults were obtained from the coast of Shanghai, China, and housed in the laboratory according to Shen's method ${ }^{22}$ in aquaculture tanks (each tank containing no more than 50 individuals), with enough fine silt and seawater (10 ppt) to simulate their natural 
living environment and shelters for the animals to hide. Feeding (corn flour and diatoms), removal of faeces and fresh seawater replacement were performed in a timely manner. The animals were allowed to acclimate to the new environment for 7 days before the experiments. For salinity stress, 150 O. reevesii individuals of the same size and weight were divided into 5 salinity groups ( 0 ppt, 5 ppt, 15 ppt, 25 ppt, 35 ppt). The water used in the experiment was saline, and the volume of water used ensured that all samples were retained. For injury stress, a surgical blade was used to inflict wounds of $\sim 5-7 \mathrm{~mm}$ long and 2-3 mm deep on the dorsal skin of 30 O. reevesii individuals; the experiment was divided into 5 groups according to the weight of the individuals: $8 \mathrm{~g}, 11 \mathrm{~g}, 15$ $\mathrm{g}, 18 \mathrm{~g}$ and $22 \mathrm{~g}$. To eliminate the influence of temperature change, the experimental temperature was maintained at approximately $25^{\circ} \mathrm{C}$, the temperature at which $O$. reevesii exhibits the best activity in the field.

\section{Sampling}

Dorsal skin tissues were used as samples in salinity stress and injury experiments; sampling was performed at $2 \mathrm{~h}, 4 \mathrm{~h}, 12 \mathrm{~h}, 24 \mathrm{~h}, 48 \mathrm{~h}$ and 7 days. Three individuals from each group were sampled at every time point ${ }^{23}$. Dorsal skin tissues were also utilized as samples for the groups of different weights. Six tissues were used for assessing gene expression, including the dorsal skin muscle, intestine, lip, pleopod, liver pancreas and gonad. All of the samples were placed in freezer tubes, frozen in liquid nitrogen and stored at $-80^{\circ} \mathrm{C}$.

\section{Total RNA extraction and first-strand cDNA synthesis}

Samples were rapidly ground in liquid nitrogen, and total RNA was extracted using TRIZOL (TaKaRa, Otsu, Japan). All RNA samples were resuspended in RNase and DNase-free $\mathrm{ddH}_{2} \mathrm{O}$ (TaKaRa, Otsu, Japan). The integrity of total RNA was determined by 1\% agarose gel electrophoresis, and a NanoDrop 2000c spectrophotometer (Thermo Scientific, Wilmington, USA) was employed to evaluate the RNA quality and concentration. RNA with a 260/280 ratio between 1.8 and 2.2 and 260/230 ratio $>1$ and $<3$ was considered satisfactory for use in experiments.

\section{Selection of internal control genes}

Seven commonly used reference genes were identified from the transcriptome of $O$. reevesii. The following are some of the criteria we applied for selecting candidate reference genes: to minimize the effect of coregulation, the nucleic acid sequence should encode a protein that plays various roles in cellular metabolism with different molecular functions; sequences that have previously been examined for stability in, to a certain extent, similar biological contexts; for reliability, the sequence should be tested specifically to verify the accuracy of the data ${ }^{24}$. Previously published candidate reference genes ${ }^{25-27}$ are cyclophilin $(C Y C)$, beta actin (ACTB), elongation factor-1 alpha (EF1a), ribosomal protein L28 (RPL28S), $\beta$-tubulin (TUBB), ubiquitin (Ubiq) and $18 S$ ribosomal RNA (18S RNA). To select corresponding sequences, all candidate genes selected from the transcriptome were analysed in the NCBI database using BLAST, and sequences were uploaded to the NCBI database to obtain the GenBank accession number (Table 1). 
112

\section{Primer design and real-time $q P C R$ assays}

The software primer 5.0 was used to design gene-specific primers. Optimized primer pairs were selected based on their amplification efficiencies and specificities ${ }^{28}$. The specificity of the PCR primers utilized was evaluated using the melting curve produced by the Applied Biosystems ${ }^{\mathrm{TM}}$ QuantStudio $^{\mathrm{TM}} 6$ Flex Real-Time PCR System (ThermoFisher, New York, USA). The fragment size of the PCR product was determined by $2.0 \%$ agarose gel electrophoresis. Primer standard curves were created using a cDNA dilution series, and amplification efficiencies were calculated using the following equation: $E=\left(10^{-1 / \text { slope }}-1\right) * 100 \%{ }^{29}$. A correction for different amplification efficiencies was introduced in the sample quantification process ${ }^{30}$.

NovoStart ${ }^{\circledR}$ Reverse Transcriptase (NOVOPROTEIN, Shanghai, China) was used to reverse transcribe $2000 \mathrm{ng}$ of total RNA from each sample into cDNA in a $20 \mu \mathrm{l}$ volume. To allow for increasing the volume of template cDNA for subsequent experiments, stock cDNA samples were diluted 5-fold for real-time PCR. Applied Biosystems ${ }^{\mathrm{TM}}$ QuantStudio $^{\mathrm{TM}} 6$ Flex Real-Time PCR System was employed for real-time PCR using a $20 \mu \mathrm{l}$ reaction system containing the following components: $2 \mu \mathrm{cDNA}$ sample, $10 \mu 12 \times$ NovoStart $^{\circledR}$ SYBR qPCR SuperMix (NOVOPROTEIN, Shanghai, China), $0.8 \mu$ l each primer, $0.4 \mu \mathrm{l}$ ROX Reference Dye II and 6.0

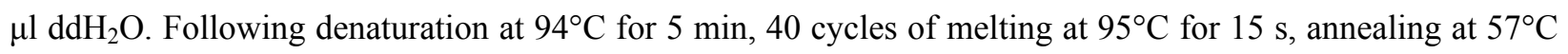
for $20 \mathrm{~s}$ and extension at $72^{\circ} \mathrm{C}$ for $30 \mathrm{~s}$ were carried out. A melting curve analysis was also performed.

\section{Data analysis}

Three software tools, geNorm, BestKeeper, and NormFinder, were used to evaluate reference gene stability according to their respective ${ }^{31-33}$. The geNorm program ranks the most stable reference genes based on the average pairwise variation of a reference gene with other selected housekeeping genes and sorts reference genes using their expression stability value (M). In general, the lower the $M$ value, the higher the expression stability. BestKeeper predicts "ideal" reference genes according to pair-wise correlation analysis among all pairs of candidate reference genes. NormFinder calculates the entire variation of candidate reference genes in all samples and also performs intragroup and intergroup comparisons. RefFinder (https://omictools.com/reffinder-tool) is a user-friendly web-based comprehensive tool developed for evaluating and screening reference genes from extensive experimental datasets. It integrates the currently available major computational programs (geNorm, NormFinder, BestKeeper) to compare and rank candidate reference genes. Based on the rankings from each program, RefFinder assigns an appropriate weight to an individual gene and calculates the geometric mean of their weights for the overall final ranking ${ }^{34}$.

\section{Results}

\section{Real-time PCR amplification efficiencies}

To ensure comparability among the 7 housekeeping genes evaluated, PCR amplification efficiencies were calculated based on the slopes resulting from the measurement of cDNA serial dilutions. All tested reference gene amplification efficiencies were in the range of 90-110\% (RPL28S (94.3\%), ACTB (97.03\%), TUBB (97.32 


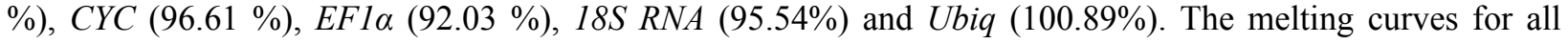
amplification products demonstrated a single peak, verifying primer-specific amplification (Supplementary Fig. S1).

\section{Expression stability of the tested genes}

Based on the statistical results of expression analyses for each housekeeping gene in the 7 different tissue types according to BestKeeper (Table 2), genes showing the lowest expression level were CYC and Ubiq, with $\mathrm{Ct}$ mean (AM[Ct]) values of 28.96 and 31.09 cycles, respectively. The genes exhibiting the highest expression levels were $A C T B, T U B B$ and $E F 1 \alpha$, with AM[Ct] values of 22.16, 23.06 and 19.75 cycles, respectively. RPL28S displayed the least variation in expression among the analysed tissues $[\mathrm{SD}( \pm \mathrm{Ct})=0.48$ ], whereas $18 S R N A$ [SD $( \pm \mathrm{Ct})=1.72]$ and $A C T B$ [SD $( \pm \mathrm{Ct})=2.67]$ showed the greatest variation. Candidate reference genes with an SD value higher than 1 must be considered unsuitable ${ }^{35}$, and the $\mathrm{M}$ value of $A C T B$ according to the geNorm program was clearly higher than 1.5. Overall, the ranking of these candidate housekeeping genes by BestKeeper, NormFinder and geNorm programs was consistent. In addition, $A C T B$ and $18 S R N A$ appeared to be less stable, whereas RPL28S, EF1 $\alpha$, and TUBB were the most stable genes (Table 2; Fig. 1 Group1, Fig. 2 A). According to geNorm, a V2/3 value of 0.15 is the proposed cut off value, under which the inclusion of an additional reference gene is not necessary (Supplementary Fig. S2 A). In this study, the V2/3 value was 0.265, and the values of $\mathrm{V} 3 / 4, \mathrm{~V} 4 / 5, \mathrm{~V} 5 / 6$, and $\mathrm{V} 6 / 7$ were all greater than 0.15 , indicating no need to include another gene in as a normalization factor. Thus, the optimal number of reference genes for normalization in this example is one. The comprehensive ranking of the seven candidate genes given by RefFinder indicated RPL28S as the best reference gene. EFla was also found to be an ideal reference gene when abundant reference gene expression is required.

\section{Expression stability in muscle of the seven genes under different}

\section{salinity treatments}

Considering that the salinity of $O$. reevesii's habitat often fluctuates greatly due to the influence of tides, river flow, rainfall and other factors, multiple salinity gradients were established to observe changes in housekeeping gene expression to explore the response of $O$. reevesii to changes in salinity (osmotic pressure regulation ability).

\section{0 ppt salinity}

Under conditions of varying salinity, BestKeeper, NormFinder, and geNorm were employed to examine the expression level of each housekeeping gene. According to BestKeeper (Table 3), the expression stability ranking of the seven reference genes for the seven sampling time points was as follows: $18 S R N A>R P L 28 S>$ $A C T B>T U B B>U b i q>E F 1 a>C Y C$. Additionally, geNorm analysis showed that TUBB, EF1a and ACTB had the highest stabilities (Fig. 1 Group 2). NormFinder analysis revealed $A C T B$ to be the gene with the greatest stability (Fig. 2 B). Because the $\mathrm{Vn} / \mathrm{n}+1$ values provided by geNorm were all greater than 0.15 , multiple housekeeping genes were not required as internal references (Supplementary Fig. S2 B). Based on the results of a comprehensive analysis by RefFinder, we recommend that $T U B B$ be used as an internal reference for qRT- 
PCR analyses of $O$. reevesii under this condition. However, when the reference gene should exhibit a high level of expression, $A C T B$ is the most appropriate choice.

\section{5 ppt salinity}

According to BestKeeper (Table 4), the expression stability ranking of the seven candidate genes was $18 S$ $R N A>R P L 28 S>E F 1 a>A C T B>T U B B>U b i q>C Y C$, an order that was slightly different from the result for the 0 ppt salinity condition. However, except for $18 S R N A(0.68)$, the $\mathrm{SD}[ \pm \mathrm{Ct}]$ values for the housekeeping genes were greater than 1. NormFinder (Fig. 1 Group3) and geNorm (Fig. 2 C) indicated EF1a, RPL28S and $T U B B$ to be the most stable genes, with $\mathrm{Vn} / \mathrm{n}+1$ values all greater than 0.15 (Supplementary Fig. S2 C). Although the results from the three software programs are inconsistent and not ideal, according to RefFinder, $R P L 28 S$ should be used as a reference gene under this condition. Due to the insufficient level of $18 S R N A$, $R P L 28 S$ and EF1a expression, $A C T B$ should be used as a reference gene under the stress of this level of salinity.

\section{5 ppt salinity}

BestKeeper results (Table 5) showed a stability ranking of expression for the seven candidate genes of $C Y C>A C T B>E F 1 a>R P L 28 S>T U B B>18 S R N A>U b i q$, which was significantly different from that of the 0 ppt and 5 ppt conditions, even though $\mathrm{SD}[ \pm \mathrm{Ct}]$ for all housekeeping genes was lower than 1 . According to NormFinder (Fig. 1 Group4) and geNorm (Fig. 2 D), EFla, ACTB, CYC and TUBB were the most stable reference genes, and the V2/3 values of 0.127 suggested that the normalization factor should preferably consist of two housekeeping genes (Supplementary Fig. S2 D). The best combination of two genes was TUBB and $E F 1 a$ (Fig. 2 D). RefFinder indicated that $T U B B$ was the most stable internal reference gene. Ubiq exhibited slightly lower expression, but $E F 1 a, A C T B$ and $C Y C$ can all be used as internal reference genes for this treatment.

\section{5 ppt salinity}

For this condition, BestKeeper results (Table 6) revealed an expression stability ranking of Ubiq $>A C T B$ $>$ EFla $>$ RPL28S $>C Y C>T U B B>18 S R N A$; however, $\mathrm{SD}[ \pm \mathrm{Ct}]$ for $18 S R N A$ was lower than 1. Different from the above conditions, the NormFinder (Fig. 1 Group5) and geNorm (Fig. 2 E) results were similar to those of BestKeeper. V2/3 values were 0.156, indicating no need for multiple housekeeping genes as internal references (Supplementary Fig. S2 E). Although the Ubiq gene was found to be the most stable, its expression level was far lower than that of the $A C T B$ gene. Therefore, the best reference gene is $A C T B$.

\section{5 ppt salinity}

$T U B B>C Y C>R P L 28 S>U b i q>A C T B>E F 1 a>18 S R N A$ was the expression stability ranking according to BestKeeper (Table 7). As with the condition of 25 ppt salinity, $\mathrm{SD}[ \pm \mathrm{Ct}]$ values were lower than 1, except for $18 S R N A$, and the NormFinder (Fig. 1 Group6) and geNorm (Fig. 2 F) results were similar to those of BestKeeper. As V2/3 values were over 0.15 , multiple housekeeping genes would not be needed (Supplementary

Fig. S2 F). The expression abundance of all candidate genes was within the acceptable range, after considering 
223

224

225

226

227

228

229

230

231

232

233

234

235

236

237

238

239

240

241

242

243

244

245

246

247

248

249

250

251

252

253

254

255

256

257

258

259

both expression stability and abundance, the best reference gene was found to be $T U B B$.

\section{Expression stability analysis of the seven genes in muscle after injury}

For each of the seven housekeeping genes, transcript abundance was assessed in three independent muscle pools collected at time points ranging from $2 \mathrm{~h}$ to 7 days after skin damage. According to BestKeeper (Table 8), the lowest level of expression gene was displayed by $U b i q$, with an $\mathrm{AM}[\mathrm{Ct}]$ value of 29.85 cycles. In contrast, $A C T B$ and $E F 1 \alpha$ showed the highest levels, with $\mathrm{AM}[\mathrm{Ct}]$ values of 18.75 and 18.92 cycles, respectively. The BestKeeper program indicated $\mathrm{SD}( \pm \mathrm{Ct})$ values lower than 1 for the reference genes other than CYC, Ubiq and 18S RNA; the geNorm M values of the seven reference genes were also lower than 1.5. BestKeeper indicated that the gene exhibiting the least variation in gene expression was $A C T B[\operatorname{SD}( \pm \mathrm{Ct})=0.46]$. However, NormFinder (Fig. 1 Group7) and geNorm (Fig. 2 G) showed TUBB to be the most stable. geNorm analysis V2/3 values were 0.137 , suggesting that the normalization factor should comprise additional housekeeping genes (Supplementary Fig. S2 G). The most suitable two-gene combination was TUBB plus EF1a (Fig. 2 G). If a single gene is used as an internal reference, RefFinder indicated EFla as the most appropriate choice.

\section{Expression stability analysis of the seven genes in individuals of different weights}

Regarding groups of $O$. reevesii of different weights, BestKeeper analysis (Table 9) revealed an $\mathrm{SD}[ \pm \mathrm{Ct}]$ lower than 1 only for $C Y C$ gene. In contrast, NormFinder (Fig. 1 Group8) and geNorm (Fig. 2 H) showed RPL28S, TUBB and EF la to be significantly more stable than the other candidate genes, with $\mathrm{Vn} / \mathrm{n}+1$ values greater than the threshold of 0.15 (Supplementary Fig. S2 H). Based on RefFinder comprehensive analysis, $R P L 28 S$ is more suitable as an internal reference gene when compared to the other candidates, similar to the results for the skin injury condition. Because a reference gene requires a high level of expression, $A C T B$ is the most appropriate reference gene for this experimental condition.

\section{Discussion}

In this study, seven genes, CYC, RPL28S, ACTB, TUBB, EF1a, Ubiq and $18 S R N A$, were selected as candidates for reference gene screening for use in $O$. reevesii. When using a relative quantification technique to analyse mRNA expression of a target gene, the final results are more accurate and scientific when appropriate internal reference genes are employed. In general, screening of internal reference genes should to meet the following criteria: it should be widely involved in all aspects of the organism's cellular metabolism; its expression should maintain a high level and stability in a range and with low sensitivity to changes in the external environment; candidate genes should be expressed stably under different experimental conditions.

Because of advantages of high timeliness, sensitivity and convenience, qRT-PCR is often used to screen reference genes. At present, there are three programs commonly used: BestKeeper, geNorm and NormFinder. However, due to the different modes in which data are processed by the respective software, there are some inconsistencies regarding the output. RefFinder comprehensively evaluates the results of the above three 
260

261

262

263

264

265

266

267

268

269

270

271

272

273

274

275

276

277

278

279

280

281

282

283

284

285

286

287

288

289

290

291

292

293

294

295

296

297

298

299

300

programs and provides a relatively reasonable internal control gene rank to help the experimenter ultimately determine the optimal choice.

We examined different salinity stress levels, skin muscle injury, different tissues of $O$. reevesii adults and individuals with different weights to identify reference genes. The most suitable internal reference genes in different tissues of Haliotis rufescens are reportedly RPL5S and CYC; the most stable in $O$. reevesii was found to be the $R P L 28 S^{36}$, but $E F 1$ a can serve as an alternative. When analysing differences in target gene expression in various tissues of $O$. reevesii, RPL28S should be used as the reference gene if the abundance of target gene expression is low, whereas EFla is recommended if target gene expression is high. Previous studies have compared the most stable internal reference genes of flatworms under salinity stress, with GM2-activator protein (GM2AP) and $A C T B$ indentified; these results are similar to those for $O$. reevesii, in which the most suitable internal control genes are $T U B B$ and $A C T B^{37}$. However, our candidate gene expression analysis showed that at low salinity (0ppt, $5 \mathrm{ppt}$ ) (low osmotic pressure environment) under laboratory conditions, expression of these genes was significantly lower than that at $15 \mathrm{ppt}$ and $25 \mathrm{ppt}$. One reason for this may be that a low osmotic pressure environment leads to excess moisture entering tissue, decreasing cellular metabolism and eventually housekeeping gene expression ${ }^{38,39}$. Nonetheless, at high salinity (35 ppt), the housekeeping genes examined essentially maintained a normal level of expression, which may be due to the strong ability of $O$. reevesii to obtain water from the external environment, ensuring the stability of its internal environment. It can be inferred from the above that $O$. reevesii is not strongly tolerant to low salinity and osmotic pressure and that its optimal living salinity is approximately $15-25 \mathrm{ppt}$. Sun found the reference genes $R P L 13 S$ and $R P L 32 S$ to be the most stably expressed in contused rat skeletal muscle; however, EFla plus TUBB constitutes the most suitable internal reference combination for $O$. reevesii after tissue damage ${ }^{40}$. Heavy metal ion stress in organisms is also a major focus of current research, and as tidal flat inhabitants, $O$. reevesii feeds on the surface soil of these flats and may very likely serve as an indicator of heavy metal ion pollution. This is a future research direction of our laboratory ${ }^{41-43}$. Although we compared data for $O$. reevesii of different sizes, because there is no consensus regarding the relationship between its growth stage and body weight, these experimental data need further confirmation. This is the first study to screen internal reference genes for $O$. reevesii under different conditions, and the results will be useful for relative quantitation of gene expression in the future.

\section{Conclusions}

In this study, we first ascertained and evaluated the expression stability of seven housekeeping genes for qRT-PCR normalization in $O$. reevesii tissues and under conditions of salinity stress and tissue injury. (1) In our assessment of different tissues, RPL28S and EFla were found to be the most suitable and stable internal genes among the six tissue samples tested as well as among individuals of different weights. (2) The results suggest that $A C T B$ and $T U B B$ are the most stable genes, with high expression levels when assessing salinity stress. (3) Regarding muscle injury, EFla is the most stable candidate gene. (4) Among all experimental groups, data analysis of two groups (15 ppt, injury) revealed $T U B B$ plus $E F 1 a$ to constitute a suitable reference combination. Based on our results, we propose that the three housekeeping genes $A C T B, T U B B$ and $E F 1 a$ be the first choice of reference genes for qRT-PCR. Our experimental data indicate that $O$. reevesii has low tolerance to low osmotic pressure and that a salinity range of approximately $15-25 \mathrm{ppt}$ is the most suitable living environment for this organism. To our knowledge, this study is the first to select and evaluate optimal reference genes for $O$. reevesii, and the findings are expected to provide theoretical data support for future experiments involving qPCR. Although the optimal internal reference gene differs among treatments, such as during salinity stress and tissue

Peer) reviewing PDF | (2018:10:31738:2:0:NEW 13 Mar 2019) 
301

302

303

304

305

306

307

308

309

$310 \quad 1$

311

$312 \quad 2$

313

314

315

316

317

318

319

320

321

322

323

324

325

326

327

$328 \quad 8$

329

$330 \quad 9$

331

$332 \quad 10$

333

334

335

336

337

338

339

340

$341 \quad 14$

injury, it is important to understand the importance of the selection of these genes. Overall, for different experimental studies of $O$. reevesii, the selection of appropriate reference genes should be taken into consideration, and our results provide basic experimental data for this purpose.

\section{Acknowledgments}

We gratefully acknowledge the assistance of Mrs. Xu in the sample collection. We also thank Wang Fei, Peng Maoxiao and Chen Ya for their advice and assistance in conducting this study.

\section{References}

1 Johnson, G., Nour, A. A., Nolan, T., Huggett, J. \& Bustin, S. Minimum Information Necessary for Quantitative Real-Time PCR Experiments. Methods in Molecular Biology 1160, 5 (2014).

2 Phillips, M. A., D'Auria, J. C., Katrin, L. \& Jonathan, G. Evaluation of Candidate Reference Genes for RealTime Quantitative PCR of Plant Samples Using Purified cDNA as Template. Plant Molecular Biology Reporter 27, 407 (2009). Jian, B., Liu, B., Bi, Y., Hou, W., Wu, C. \& Han, T. Validation of internal control for gene expression study in soybean by quantitative real-time PCR. Bmc Molecular Biology 9, 1-14 (2008).

Yang, Y., Li, S., Wong, G., Ma, S., Xu, Z., Zhao, X., Hong, L., Wen, X., Zheng, H. \& Lin, J. Development of a quadruple qRT-PCR assay for simultaneous identification of highly and low pathogenic $\mathrm{H} 7 \mathrm{~N} 9$ avian influenza viruses and characterization against oseltamivir resistance. Bmc Infectious Diseases 18, 406- (2018). Leidinger, P., Brefort, T., Backes, C., Krapp, M., Galata, V., Beier, M., Kohlhaas, J., Huwer, H., Meese, E. \& Keller, A. High-throughput qRT-PCR validation of blood microRNAs in non-small cell lung cancer. Oncotarget 7, 4611-4623 (2016).

6 Chervoneva, I., Freydin, B., Hyslop, T. \& Waldman, S. A. Modeling qRT-PCR dynamics with application to cancer biomarker quantification. Statistical Methods in Medical Research, 962280216683204 (2017).

7 Bustin, S. A., Benes, V., Garson, J. A., Hellemans, J., Huggett, J., Kubista, M., Mueller, R., Nolan, T., Pfaffl, M. W. \& Shipley, G. L. The MIQE guidelines: minimum information for publication of quantitative real-time PCR experiments. Clinical Chemistry 55, 611-622 (2009).

8 Huggett, J., Dheda, K., Bustin, S. \& Zumla, A. Real-time RT-PCR normalisation; strategies and considerations. Genes \& Immunity 6, 279-284 (2005).

Bustin, S. A. Bustin, S. A. Quantification of mRNA using real-time reverse transcription PCR (RT-PCR): trends and problems. J Mol Endocrinol. Journal of Molecular Endocrinology 29, 23-39 (2002). Huan, P., Wang, H. \& Liu, B. Assessment of housekeeping genes as internal references in quantitative expression analysis during early development of oyster. Genes \& Genetic Systems 91, 257 (2017).

11 Song, H., Dang, X., He, Y., Zhang, T. \& Wang, H. Selection of housekeeping genes as internal controls for quantitative RT-PCR analysis of the veined rapa whelk (Rapana venosa). Peerj 5, e3398 (2017).

12 Gao, M., Liu, Y., Ma, X., Shuai, Q., Gai, J. \& Li, Y. Evaluation of Reference Genes for Normalization of Gene Expression Using Quantitative RT-PCR under Aluminum, Cadmium, and Heat Stresses in Soybean. Plos One 12, e0168965 (2017).

$13 \mathrm{Hu}, \mathrm{Y} ., \mathrm{Xie}, \mathrm{S}$. \& Yao, J. Identification of Novel Reference Genes Suitable for qRT-PCR Normalization with Respect to the Zebrafish Developmental Stage. Plos One 11, e0149277 (2016).

4 Vandesompele, J., De, P. K., Pattyn, F., Poppe, B., Van, R. N., De, P. A. \& Speleman, F. Accurate normalization 
of real-time quantitative RT-PCR data by geometric averaging of multiple internal control genes. Genome Biology 3 (2002).

15 Wang, D., Xu, G., Jing, Q., Shen, H., Zhang, K. \& Ju, G. A morphological description of Onchidium reevesii (Gastropoda: Eupulmonata: Systellommatophora). Molluscan Research, 1-8 (2018).

16 Sun, B., Chen, C., Shen, H., Zhang, K., Qian, N. Z. \& Jing. Species diversity of Onchidiidae (Eupulmonata: Heterobranchia) on the mainland of China based on molecular data. Molluscan Research 34, 62-70 (2014).

17 Guan, J., Shen, H., Qian, J., Zhang, K. \& Zheng, P. Analysis and evaluation of mutritive composition of four species of Onchidiidae. Science and Technology of Food Industry 34, 349-353 (2013).

18 Sun, B. N., Wei, L. L., Shen, H. D., Wu, H. X. \& Wang, D. F. Phylogenetic analysis of euthyneuran gastropods from sea to land mainly based on comparative mitogenomic of four species of Onchidiidae (Mollusca: Gastropoda: Pulmonata). Mitochondrial Dna Part A Dna Mapping Sequencing \& Analysis 27, 3075 (2016). Wang, C. Genetic structure of (Mollusca: Gastropoda: Eupulmonata) from the coastal area of China based on mtl. Mitochondrial Dna 39, 1-5 (2014).

Shen, H., Wang, L., Dai, X. \& Shi, Z. Karyotypes in Onchidium struma (Gastropoda: Pulmonata: Systellommatophora). Molluscan Research 30, 113-116 (2010).

21 Cheng, Z., Shen, H., Yao, L. \& Diao, Y. Biological Activity Status and Medicinal Value of Shellfish Polysaccharide. Journal of Anhui Agricultural, 17-19 (2015).

22 Shen, H., Chen, H., Chen, X., Sun, H., Hua, X. \& Xiao, H. Preliminary studies on the absorption rates and the feeding effects of different diets on sea-slug Onchidium sp. Journal of shanghai Ocean University 13, 293297 (2004).

23 Bai, Z., Lin, J., Ma, K., Wang, G., Niu, D. \& Li, J. Identification of housekeeping genes suitable for gene expression analysis in the pearl mussel, Hyriopsis cumingii , during biomineralization. Molecular Genetics \& Genomics 289, 717-725 (2014).

24 Die, J. V., Baldwin, R. L., Rowland, L. J., Li, R., Oh, S., Li, C., Connor, E. E. \& Ranilla, M. J. Selection of internal reference genes for normalization of reverse transcription quantitative polymerase chain reaction (RTqPCR) analysis in the rumen epithelium. Plos One 12, e0172674 (2017).

Purohit, G. K., Mahanty, A., Mohanty, B. P. \& Mohanty, S. Evaluation of housekeeping genes as references for quantitative real-time PCR analysis of gene expression in the murrel Channa striatus under hightemperature stress. Fish Physiology \& Biochemistry 42, 1-11 (2015).

26 Altmann, S., Rebl, A., Kühn, C. \& Goldammer, T. Identification and de novo sequencing of housekeeping genes appropriate for gene expression analyses in farmed maraena whitefish (Coregonus maraena) during crowding stress. Fish Physiology \& Biochemistry 41, 397 (2015).

27 Etich, J., Bergmeier, V., Pitzler, L. \& Brachvogel, B. Identification of a reference gene for the quantification of mRNA and miRNA expression during skin wound healing. Connective Tissue Research (2016).

28 D'Haene, B., Vandesompele, J. \& Hellemans, J. Accurate and objective copy number profiling using realtime quantitative PCR. Methods 50, 262 (2010).

29 Radonić, A., Thulke, S., Mackay, I. M., Landt, O., Siegert, W. \& Nitsche, A. Guideline to reference gene selection for quantitative real-time PCR. Biochemical \& Biophysical Research Communications 313, 856-862 (2004).

30 Marino, J. H. \& Cook PMiller, K. S. Accurate and statistically verified quantification of relative mRNA abundances using SYBR Green I and real-time RT-PCR. Journal of Immunological Methods 283, 291 (2003).

Peer) reviewing PDF | (2018:10:31738:2:0:NEW 13 Mar 2019) 
383

384

385

386

387

388

389

390

391

392

393

394

395

396

397

398

399

400

401

402

403

404

405

406

407

408

409

410

411

412

413

414

$415 \quad 43$

416

417
31 Vandesompele, J., Preter, K. D., Pattyn, F., Poppe, B., Roy, N. V., Paepe, A. D. \& Speleman, F. Accurate normalization of real-time quantitative RT-PCR data by geometric averaging of multiple internal control genes. Genome Biology 3 (2002).

32 Andersen, C. L., Jensen, J. L. \& TF, $\varnothing$. Normalization of real-time quantitative reverse transcription-PCR data: a model-based variance estimation approach to identify genes suited for normalization, applied to bladder and colon cancer data sets. Cancer Research 64, 5245 (2004).

33 Pfaffl, M. W., Tichopad, A., Prgomet, C. \& Neuvians, T. P. Determination of stable housekeeping genes, differentially regulated target genes and sample integrity: BestKeeper--Excel-based tool using pair-wise correlations. Biotechnology Letters 26, 509-515 (2004).

34 Kim, M., Gee, M., Loh, A. \& Rachatasumrit, N. in Eighteenth ACM Sigsoft International Symposium on Foundations of Software Engineering. 371-372.

35 Mehta, R., Birerdinc, A., Hossain, N., Afendy, A., Chandhoke, V., Younossi, Z. \& Baranova, A. Validation of endogenous reference genes for qRT-PCR analysis of human visceral adipose samples. Bmc Molecular Biology 11, 1-10 (2010).

36 López-Landaverya, E. A., Portillo-Lópezb, A., Gallardo-Escáratec, C. \& Miguel A. Del Río-Portillaa. Selection of reference genes as internal controls for gene expression in tissues of red abalone Haliotis rufescens (Mollusca, Vetigastropoda; Swainson, 1822). GENE, 258-265 (2014).

37 Plusquin, M., Degheselle, O., Cuypers, A., Geerdens, E., Van, R. A., Artois, T. \& Smeets, K. Reference genes for qPCR assays in toxic metal and salinity stress in two flatworm model organisms. Ecotoxicology 21, 475484 (2012).

38 Mizuno, S. \& Ogawa, R. Using changes in hydrostatic and osmotic pressure to manipulate metabolic function in chondrocytes. Am J Physiol Cell Physiol 300, C1234 (2011).

$39 \varnothing \mathrm{RSKOV}, \mathrm{S}$. L. The Volume of the Erythrocytes at Different Osmotic Pressure. Further Experiments on the Influence of Lead on the Permeability of Cations. Acta Physiologica Scandinavica 12, 202-212 (2010).

40 Sun, J. H., Nan, L. H., Gao, C. R. \& Wang, Y. Y. Validation of reference genes for estimating wound age in contused rat skeletal muscle by quantitative real-time PCR. International Journal of Legal Medicine 126, 113-120 (2012).

41 Alcalá Jáuregui, J., Rodríguez Ortíz, J. C., Hernández Montoya, A., Diaz Flores, P. E., Filippini, M. F. \& Martínez Carretero, E. Bark of P. laevigata (Fabaceae) and S. molle (Anacardiaceae) as bioindicator of heavy metal contamination. Revista De La Facultad De Ciencias Agrarias Universidad Nacional De Cuyo 47, 83-95 (2015). Aydın-Önen, S. Styela plicata: a new promising bioindicator of heavy metal pollution for eastern Aegean Sea coastal waters. Environ Sci Pollut Res Int 23, 21536-21553 (2016).

43 Authman, M. M. N., Zaki, M. S., Khallaf, E. A. \& Abbas, H. H. Use of fish as bio-indicator of the effects of heavy metals pollution. Journal of Aquaculture Research \& Development 06, 328 (2015). 
Figure 1

Stability values of the seven housekeeping genes evaluated by NormFinder

Different tissues (Group1); dorsal muscle tissue under 0 ppt salinity (Group2); dorsal muscle tissue under 5 ppt salinity (Group3); dorsal muscle tissue under 15 ppt salinity (Group4); dorsal muscle tissue under 25 ppt salinity (Group5); dorsal muscle tissue under 35 ppt salinity (Group6); dorsal muscle tissue after injury (Group7); dorsal muscle tissue from animals of different weights (Group8)

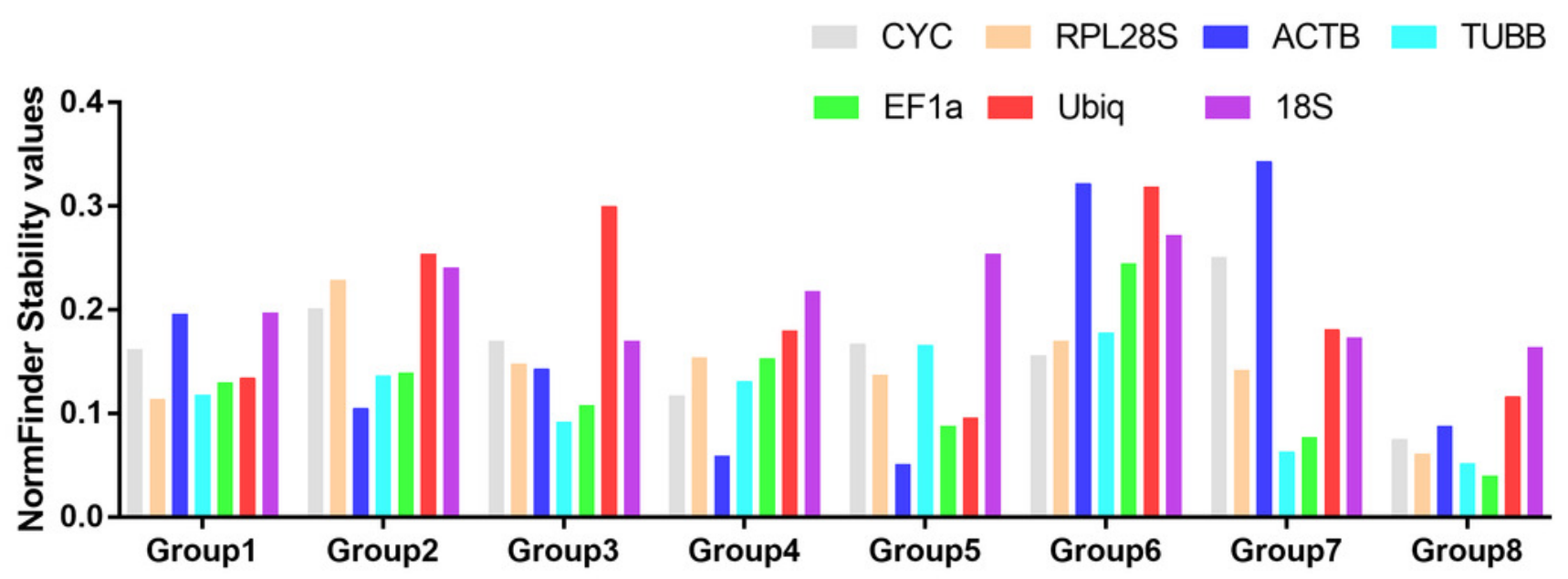

Grouping of Different Experimental Conditions 
Figure 2 (on next page)

Average expression stability values of housekeeping genes analysed by geNorm.

A Different tissues; $B$ dorsal muscle tissue under $\mathbf{0}$ ppt salinity; $\mathrm{C}$ dorsal muscle tissue under 5 ppt salinity; D dorsal muscle tissue under $\mathbf{1 5}$ ppt salinity; E dorsal muscle tissue under $\mathbf{2 5}$ ppt salinity; F dorsal muscle tissue under $\mathbf{3 5}$ ppt salinity; $G$ dorsal muscle tissue after injury; $\mathrm{H}$ dorsal muscle tissue from animals of different weights. 
A

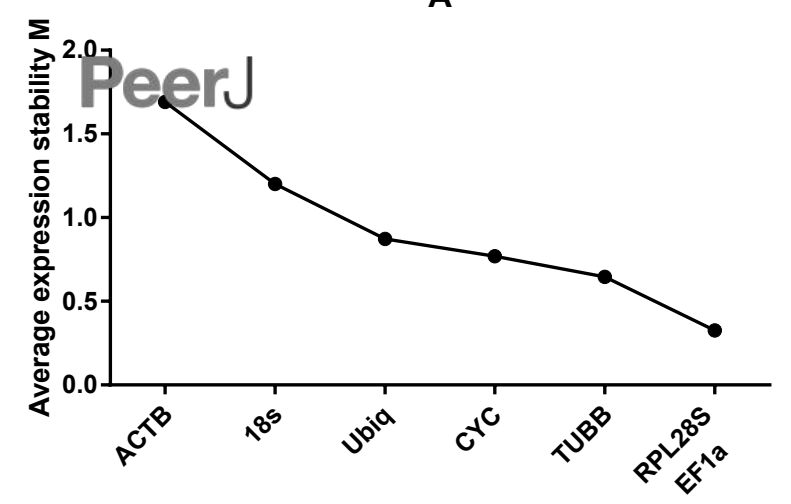

C

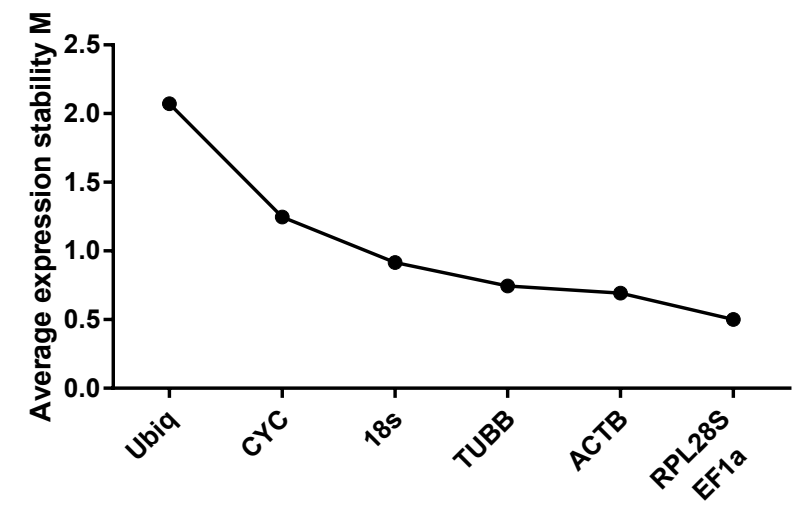

E

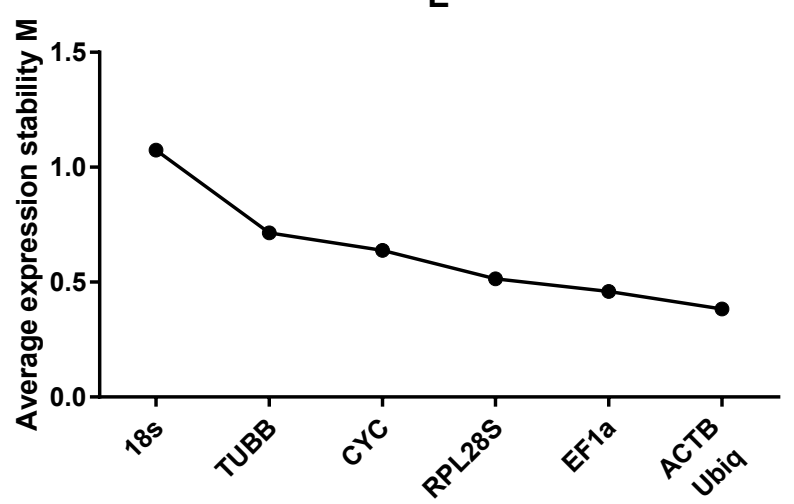

G

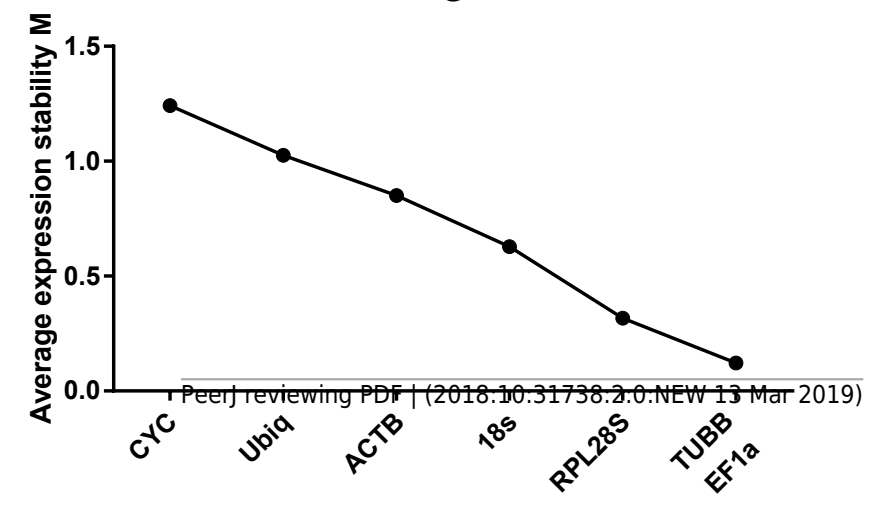

Least stable genes

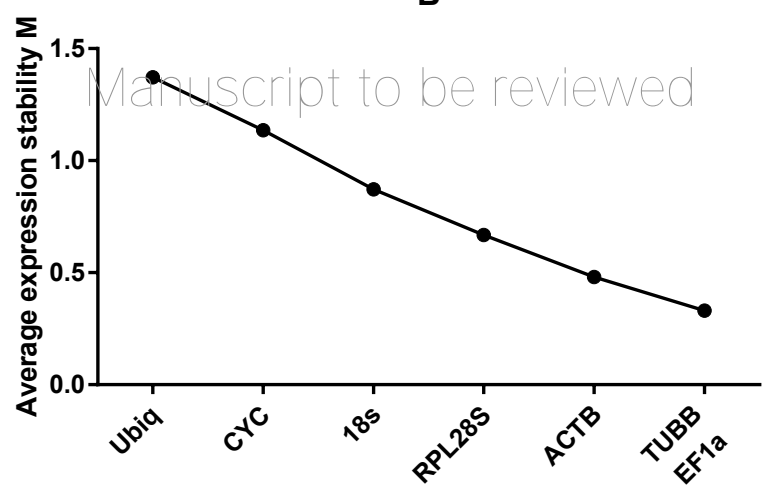

D

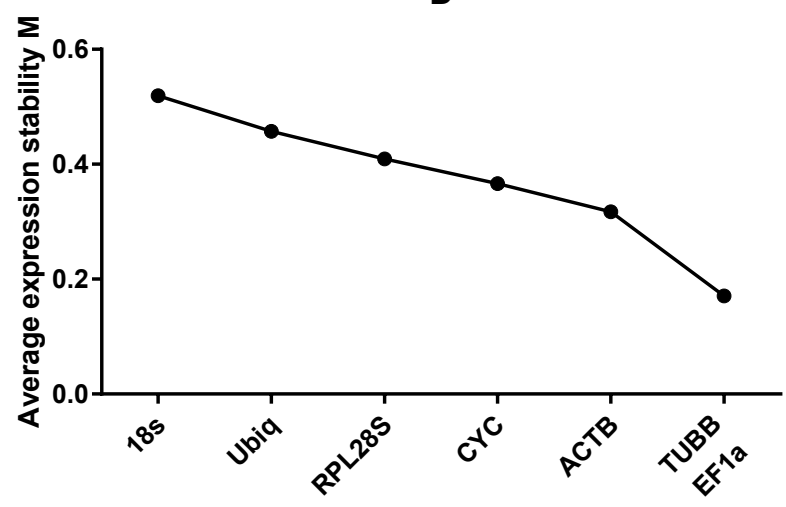

$\mathbf{F}$

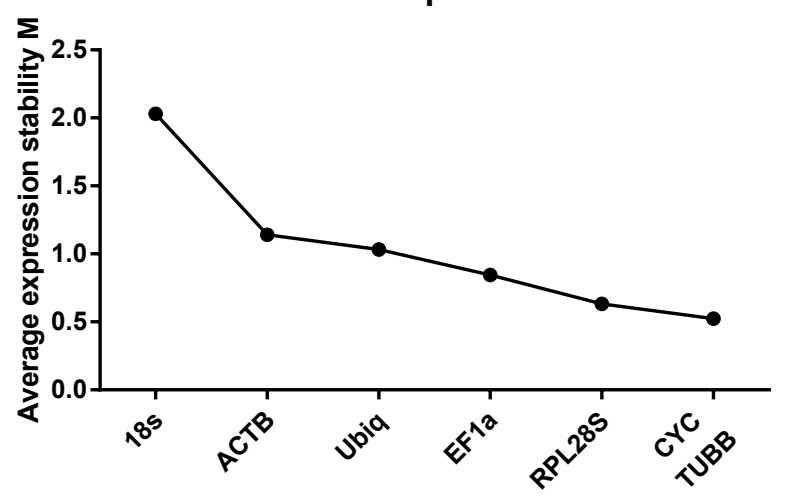

H

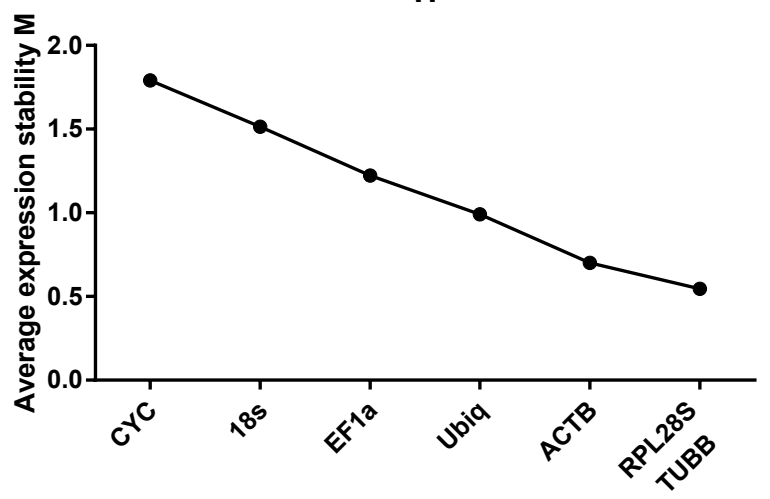

Least stable genes Most stable geens 
Table $\mathbf{1}$ (on next page)

Details of the primers used for qRT-PCR normalization 


\begin{tabular}{|c|c|c|c|c|c|}
\hline $\begin{array}{l}\text { Gene } \\
\text { abbreviation }\end{array}$ & $\begin{array}{l}\text { Gene } \\
\text { name }\end{array}$ & Biological function & Primer sequence (5'-3') & $\begin{array}{l}\text { Product size } \\
\text { (bp) }\end{array}$ & $\begin{array}{l}\text { Accession } \\
\text { No. }\end{array}$ \\
\hline$C Y C$ & cyclophilin & $\begin{array}{l}\text { Immunosuppressant, } \\
\text { protein folding }\end{array}$ & $\begin{array}{l}\text { F: GTGGGATGTTCCTCTTTACC } \\
\text { R: ACCTGGGATTATTCTGTGG }\end{array}$ & 269 & KY593122 \\
\hline RPL28 & $\begin{array}{l}\text { Ribosomal } \\
\text { protein } l \\
28\end{array}$ & $\begin{array}{l}60 \mathrm{~S} \text { ribosomal } \\
\text { subunit }\end{array}$ & $\begin{array}{l}\text { F: CTGGCACAGGCAAAGTGTCC } \\
\text { R: } \\
\text { GCAGTGAGAGCCTTGGCTAGA }\end{array}$ & 196 & KY593120 \\
\hline$A C T B$ & $\beta$-actin & $\begin{array}{l}\text { Cytoskeletal } \\
\text { structural protein }\end{array}$ & $\begin{array}{l}\text { F: GTCCACCGCAAGTGCTTCT } \\
\text { R: CGGTCGTGGTTGTTTCATT }\end{array}$ & 214 & KY593121 \\
\hline$T U B B$ & $\beta$-tubulin & Structural protein & $\begin{array}{l}\text { F: GTGCTGTTGCCGATGAAAG } \\
\text { R: GCATGTCCATGAAGGAGGTT }\end{array}$ & 157 & KY593125 \\
\hline$E F 1 \alpha$ & $\begin{array}{l}\text { elongation } \\
\text { factor } 1 \text { - } \\
\text { alpha }\end{array}$ & $\begin{array}{l}\text { Essential component } \\
\text { of the eukaryotic } \\
\text { translational } \\
\text { apparatus }\end{array}$ & $\begin{array}{l}\text { F: GGAGATGCCAGCCTCAAAC } \\
\text { R: GATATTGCGTTGTGGAAGT }\end{array}$ & 165 & KY593123 \\
\hline Ubiq & Ubiquitin & Protein degradation & $\begin{array}{l}\text { F: GCCGAGGCTACATTCCAGT } \\
\text { R: } \\
\text { GAAGCTTGACATGACCACGAT }\end{array}$ & 203 & MF680835 \\
\hline $18 S R N A$ & $18 S r R N A$ & $\begin{array}{l}\text { rRNA in the } \\
\text { ribosome }\end{array}$ & $\begin{array}{l}\text { F: TCCGCAGGAGTTGCTTCGAT } \\
\text { R: ATTAAGCCGCAGGCTCCACT }\end{array}$ & 142 & FJ843070 \\
\hline
\end{tabular}

Table 1 Details of the primers used for $q R T-P C R$ normalization. 


\section{Table 2 (on next page)}

Statistical results and expression analyses of the tested reference genes in different tissues, as based of threshold cycle point values $(\mathrm{Ct})$ provided by BestKeeper.

$\mathrm{N}$ number of samples, $\mathrm{Ct}$ threshold cycle point value, GM[Ct] geometric ct mean, AM[Ct] arithmetic ct mean, $\operatorname{Min}[\mathrm{Ct}]$ and $\operatorname{Max}[\mathrm{Ct}] \mathrm{ct}$ threshold values, $\mathrm{SD}[ \pm \mathrm{Ct}]$ ct standard deviation, $\mathrm{CV}[\% \mathrm{Ct}]$ variance coefficient expressed as a percentage of the ct level, Min[x-fold] and Max[x-fold] threshold expression levels expressed as the absolute $x$-fold over- or underregulation coefficient, $\mathrm{SD}[ \pm \mathrm{x}$-fold] standard deviation of the absolute regulation coefficient . 


\begin{tabular}{|l|c|c|c|c|c|c|c|}
\hline Factor & CYC & RPL28S & ACTB & TUBB & EFla & Ubiq & $\begin{array}{c}18 S \\
R N A\end{array}$ \\
\hline $\mathrm{N}$ & 6 & 6 & 6 & 6 & 6 & 6 & 6 \\
\hline $\mathrm{GM}[\mathrm{Ct}]$ & 28.94 & 27.76 & 21.98 & 23.05 & 19.73 & 31.07 & 22.58 \\
\hline $\mathrm{AM}[\mathrm{Ct}]$ & 28.96 & 27.77 & 22.16 & 23.06 & 19.75 & 31.09 & 22.65 \\
\hline $\mathrm{Min}[\mathrm{Ct}]$ & 27.88 & 26.88 & 18.75 & 21.74 & 19.1 & 29.96 & 20.08 \\
\hline $\mathrm{Max}[\mathrm{Ct}]$ & 30 & 28.92 & 26.91 & 24.4 & 21.35 & 33.09 & 25.18 \\
\hline $\mathrm{SD}[ \pm \mathrm{Ct}]$ & 0.89 & 0.48 & 2.67 & 0.77 & 0.66 & 0.94 & 1.72 \\
\hline $\mathrm{CV}[\% \mathrm{Ct}]$ & 3.09 & 1.74 & 12.05 & 3.33 & 3.33 & 3.01 & 7.58 \\
\hline $\mathrm{Min}[\mathrm{x}-\mathrm{fold}]$ & -2.09 & -1.84 & -9.37 & -2.47 & -1.55 & -2.17 & -5.63 \\
\hline $\mathrm{Max}[\mathrm{x}-$ fold] & 2.09 & 2.23 & 30.66 & 2.56 & 3.08 & 4.06 & 6.08 \\
\hline $\begin{array}{l}\mathrm{SD}[ \pm \mathrm{x}- \\
\text { fold }]\end{array}$ & 1.86 & 1.4 & 6.37 & 1.7 & 1.58 & 1.91 & 3.29 \\
\hline
\end{tabular}

1 Table 2 Statistical results and expression level analyses of all tested candidate reference genes in 2 different tissues on account of their threshold cycle point values $(\mathrm{Ct})$ as furnished by BestKeeper 3 program. 


\section{Table 3(on next page)}

Statistical results and expression analysis of candidate reference genes under $0 \mathrm{ppt}$ salinity, as based on threshold cycle point values $(\mathrm{Ct})$ provided by BestKeeper. 


\begin{tabular}{|l|c|c|c|c|c|c|c|}
\hline Factor & CYC & RPL28S & ACTB & TUBB & EFla & Ubiq & $\begin{array}{c}18 S \\
R N A\end{array}$ \\
\hline $\mathrm{N}$ & 7 & 7 & 7 & 7 & 7 & 7 & 7 \\
\hline $\mathrm{GM}[\mathrm{Ct}]$ & 32.12 & 31.65 & 23.24 & 28.08 & 28.6 & 36.19 & 32.65 \\
\hline $\mathrm{AM}[\mathrm{Ct}]$ & 32.19 & 31.66 & 23.26 & 28.1 & 28.62 & 36.22 & 32.66 \\
\hline $\mathrm{Min}[\mathrm{Ct}]$ & 29.13 & 30.72 & 22.43 & 26.65 & 27.16 & 33.23 & 31.52 \\
\hline $\mathrm{Max}[\mathrm{Ct}]$ & 35.74 & 33 & 24.98 & 30.03 & 30.36 & 38.13 & 33.55 \\
\hline $\mathrm{SD}[ \pm \mathrm{Ct}]$ & 1.65 & 0.69 & 0.7 & 0.95 & 1.14 & 1.08 & 0.64 \\
\hline $\mathrm{CV}[\% \mathrm{Ct}]$ & 5.13 & 2.19 & 3.02 & 3.38 & 3.98 & 2.98 & 1.96 \\
\hline $\mathrm{Min}[\mathrm{x}-\mathrm{fold}]$ & -7.98 & -1.91 & -1.75 & -2.69 & -2.71 & -7.77 & -2.19 \\
\hline $\mathrm{Max}[\mathrm{x}-$ fold $]$ & 12.24 & 2.55 & 3.35 & 3.87 & 3.39 & 3.82 & 1.86 \\
\hline $\begin{array}{l}\mathrm{SD}[ \pm \mathrm{x}- \\
\text { fold }]\end{array}$ & 3.14 & 1.62 & 1.63 & 1.93 & 2.2 & 2.11 & 1.56 \\
\hline
\end{tabular}

1 Table 3 Statistical results and expression level analyses of all tested candidate reference genes under 2 culturing environment in salinity of 0 ppt on account of their threshold cycle point values $(\mathrm{Ct})$ as 3 furnished by BestKeeper program. 


\section{Table 4 (on next page)}

Statistical results and expression analysis of candidate reference genes under $5 \mathrm{ppt}$ salinity, as based on threshold cycle point values (Ct) provided by BestKeeper. 


\begin{tabular}{|l|c|c|c|c|c|c|c|}
\hline Factor & CYC & RPL28S & ACTB & TUBB & EFla & Ubiq & $\begin{array}{c}18 S \\
R N A\end{array}$ \\
\hline $\mathrm{N}$ & 7 & 7 & 7 & 7 & 7 & 7 & 7 \\
\hline $\mathrm{GM}[\mathrm{Ct}]$ & 33.15 & 30.59 & 23.35 & 27.22 & 28.48 & 35.1 & 32.13 \\
\hline $\mathrm{AM}[\mathrm{Ct}]$ & 33.26 & 30.63 & 23.41 & 27.29 & 28.52 & 35.18 & 32.14 \\
\hline $\mathrm{Min}[\mathrm{Ct}]$ & 28.87 & 29.51 & 21.44 & 25.37 & 26.78 & 30.01 & 31.06 \\
\hline $\mathrm{Max}[\mathrm{Ct}]$ & 38.67 & 33.94 & 27.08 & 32.12 & 32 & 37.79 & 34.17 \\
\hline $\mathrm{SD}[ \pm \mathrm{Ct}]$ & 2.03 & 1.35 & 1.48 & 1.58 & 1.37 & 1.79 & 0.68 \\
\hline $\mathrm{CV}[\% \mathrm{Ct}]$ & 6.1 & 4.4 & 6.31 & 5.8 & 4.79 & 5.09 & 2.11 \\
\hline $\mathrm{Min}[\mathrm{x}-\mathrm{fold}]$ & -19.39 & -2.11 & -3.75 & -3.6 & -3.25 & -34.04 & -2.09 \\
\hline $\mathrm{Max}[\mathrm{x}-$ fold $]$ & 46 & 10.21 & 13.26 & 29.88 & 11.54 & 6.45 & 4.12 \\
\hline $\begin{array}{l}\mathrm{SD}[ \pm \mathrm{x}- \\
\text { fold] }\end{array}$ & 4.08 & 2.55 & 2.78 & 3 & 2.58 & 3.46 & 1.6 \\
\hline
\end{tabular}

1 Table 4 Statistical results and expression level analyses of all tested candidate reference genes under 2 culturing environment in salinity of 5 ppt based on their threshold cycle point values $(\mathrm{Ct})$ as provided by 3 BestKeeper software. 


\section{Table 5 (on next page)}

Statistical results and expression analysis of candidate reference genes under $15 \mathrm{ppt}$ salinity, as based on threshold cycle point values (Ct) provided by BestKeeper. 


\begin{tabular}{|l|c|c|c|c|c|c|c|}
\hline Factor & CYC & RPL28S & ACTB & TUBB & EFla & Ubiq & $\begin{array}{c}18 S \\
R N A\end{array}$ \\
\hline $\mathrm{N}$ & 7 & 7 & 7 & 7 & 7 & 7 & 7 \\
\hline $\mathrm{GM}[\mathrm{Ct}]$ & 20.59 & 27.49 & 19.39 & 22.78 & 19.88 & 30.7 & 21.21 \\
\hline $\mathrm{AM}[\mathrm{Ct}]$ & 20.59 & 27.49 & 19.39 & 22.79 & 19.89 & 30.71 & 21.22 \\
\hline $\mathrm{Min}[\mathrm{Ct}]$ & 20.18 & 26.95 & 18.41 & 21.91 & 19.17 & 29.83 & 20.51 \\
\hline $\mathrm{Max}[\mathrm{Ct}]$ & 20.95 & 28.02 & 19.89 & 23.42 & 20.33 & 31.56 & 22.46 \\
\hline $\mathrm{SD}[ \pm \mathrm{Ct}]$ & 0.26 & 0.34 & 0.3 & 0.36 & 0.32 & 0.58 & 0.51 \\
\hline $\mathrm{CV}[\% \mathrm{Ct}]$ & 1.25 & 1.23 & 1.55 & 1.6 & 1.61 & 1.89 & 2.42 \\
\hline $\mathrm{Min}[\mathrm{x}-\mathrm{fold}]$ & -1.33 & -1.46 & -1.98 & -1.83 & -1.64 & -1.83 & -1.63 \\
\hline $\mathrm{Max}[\mathrm{x}-$ fold $]$ & 1.29 & 1.44 & 1.42 & 1.56 & 1.36 & 1.81 & 2.39 \\
\hline $\begin{array}{l}\mathrm{SD}[ \pm \mathrm{x}- \\
\text { fold] }\end{array}$ & 1.2 & 1.26 & 1.23 & 1.29 & 1.25 & 1.49 & 1.43 \\
\hline
\end{tabular}

1 Table 5 Statistical results and expression level analyses of all tested candidate reference genes under 2 culturing environment in salinity of $15 \mathrm{ppt}$ on account of their threshold cycle point values (Ct) as 3 furnished by BestKeeper program. 


\section{Table 6(on next page)}

Statistical results and expression analysis of candidate reference genes under $25 \mathrm{ppt}$ salinity, as based on threshold cycle point values (Ct) provided by BestKeeper. 


\begin{tabular}{|l|c|c|c|c|c|c|c|}
\hline Factor & CYC & RPL28S & ACTB & TUBB & EFla & Ubiq & $\begin{array}{c}18 S \\
R N A\end{array}$ \\
\hline $\mathrm{N}$ & 7 & 7 & 7 & 7 & 7 & 7 & 7 \\
\hline $\mathrm{GM}[\mathrm{Ct}]$ & 22.22 & 27.75 & 19.44 & 20.35 & 18.48 & 31.5 & 20.77 \\
\hline $\mathrm{AM}[\mathrm{Ct}]$ & 22.23 & 27.75 & 19.44 & 20.37 & 18.49 & 31.5 & 20.86 \\
\hline $\mathrm{Min}[\mathrm{Ct}]$ & 20.76 & 26.82 & 19.14 & 19.09 & 17.5 & 31.1 & 19.32 \\
\hline $\mathrm{Max}[\mathrm{Ct}]$ & 23.4 & 28.62 & 20.6 & 21.86 & 19.85 & 31.9 & 25.25 \\
\hline $\mathrm{SD}[ \pm \mathrm{Ct}]$ & 0.64 & 0.58 & 0.33 & 0.87 & 0.52 & 0.22 & 1.57 \\
\hline $\mathrm{CV}[\% \mathrm{Ct}]$ & 2.88 & 2.07 & 1.72 & 4.27 & 2.8 & 0.71 & 7.54 \\
\hline $\mathrm{Min}[\mathrm{x}-\mathrm{fold}]$ & -2.74 & -1.9 & -1.23 & -2.39 & -1.97 & -1.31 & -2.72 \\
\hline $\mathrm{Max}[\mathrm{x}-$ fold $]$ & 2.26 & 1.83 & 2.23 & 2.85 & 2.59 & 1.32 & 22.39 \\
\hline $\begin{array}{l}\mathrm{SD}[ \pm \mathrm{x}- \\
\text { fold] }\end{array}$ & 1.56 & 1.49 & 1.26 & 1.83 & 1.43 & 1.17 & 2.97 \\
\hline
\end{tabular}

1 Table 6 Statistical results and expression level analyses of all tested candidate reference genes under 2 culturing environment in salinity of $25 \mathrm{ppt}$ on account of their threshold cycle point values (Ct) as 3 furnished by BestKeeper program. 


\section{Table 7 (on next page)}

Statistical results and expression analysis of candidate reference genes under $35 \mathrm{ppt}$ salinity, as based on threshold cycle point values (Ct) provided by BestKeeper. 


\begin{tabular}{|l|c|c|c|c|c|c|c|}
\hline Factor & CYC & RPL28S & ACTB & TUBB & EFla & Ubiq & $\begin{array}{c}18 S \\
R N A\end{array}$ \\
\hline $\mathrm{N}$ & 7 & 7 & 7 & 7 & 7 & 7 & 7 \\
\hline $\mathrm{GM}[\mathrm{Ct}]$ & 24.39 & 27.03 & 18.79 & 21.77 & 20.32 & 29.85 & 23.25 \\
\hline $\mathrm{AM}[\mathrm{Ct}]$ & 24.4 & 27.04 & 18.82 & 21.78 & 20.35 & 29.86 & 23.68 \\
\hline $\mathrm{Min}[\mathrm{Ct}]$ & 23.66 & 25.9 & 16.83 & 21.3 & 19.05 & 28.34 & 17.98 \\
\hline $\mathrm{Max}[\mathrm{Ct}]$ & 25.23 & 28.11 & 20.13 & 22.63 & 21.48 & 31.27 & 31.93 \\
\hline $\mathrm{SD}[ \pm \mathrm{Ct}]$ & 0.44 & 0.51 & 0.77 & 0.34 & 0.89 & 0.64 & 3.79 \\
\hline $\mathrm{CV}[\% \mathrm{Ct}]$ & 1.8 & 1.9 & 4.1 & 1.57 & 4.36 & 2.16 & 16 \\
\hline $\mathrm{Min}[\mathrm{x}-\mathrm{fold}]$ & -1.66 & -2.19 & -3.9 & -1.39 & -2.41 & -2.85 & -38.68 \\
\hline $\mathrm{Max}[\mathrm{x}-$ fold $]$ & 1.79 & 2.12 & 2.52 & 1.81 & 2.24 & 2.66 & 410.85 \\
\hline $\begin{array}{l}\mathrm{SD}[ \pm \mathrm{x}- \\
\text { fold] }\end{array}$ & 1.35 & 1.43 & 1.71 & 1.27 & 1.85 & 1.56 & 13.83 \\
\hline
\end{tabular}

1 Table 7 Statistical results and expression level analyses of all tested candidate reference genes under 2 culturing environment in salinity of $35 \mathrm{ppt}$ on account of their threshold cycle point values (Ct) as 3 furnished by BestKeeper program. 
Table 8(on next page)

Statistical results and expression level analysis of candidate reference genes during skin muscle healing, as based on threshold cycle point values ( $\mathrm{Ct}$ ) provided by BestKeeper. 


\begin{tabular}{|l|c|c|c|c|c|c|c|}
\hline Factor & CYC & RPL28S & ACTB & TUBB & EFla & Ubiq & $\begin{array}{c}18 S \\
R N A\end{array}$ \\
\hline $\mathrm{N}$ & 7 & 7 & 7 & 7 & 7 & 7 & 7 \\
\hline $\mathrm{GM}[\mathrm{Ct}]$ & 25.26 & 27.14 & 18.75 & 22.3 & 18.92 & 29.85 & 20.99 \\
\hline $\mathrm{AM}[\mathrm{Ct}]$ & 25.33 & 27.15 & 18.76 & 22.31 & 18.94 & 29.87 & 21.03 \\
\hline $\mathrm{Min}[\mathrm{Ct}]$ & 23.28 & 26.07 & 17.38 & 21.52 & 18.21 & 27.6 & 19.03 \\
\hline $\mathrm{Max}[\mathrm{Ct}]$ & 28.32 & 28.19 & 19.67 & 23.8 & 20.32 & 31.68 & 23.12 \\
\hline $\mathrm{SD}[ \pm \mathrm{Ct}]$ & 1.6 & 0.63 & 0.46 & 0.52 & 0.57 & 1.01 & 1.05 \\
\hline $\mathrm{CV}[\% \mathrm{Ct}]$ & 6.32 & 2.33 & 2.43 & 2.31 & 3 & 3.37 & 4.98 \\
\hline $\mathrm{Min}[\mathrm{x}-\mathrm{fold}]$ & -3.96 & -2.1 & -2.58 & -1.71 & -1.64 & -4.75 & -3.91 \\
\hline $\mathrm{Max}[\mathrm{x}-$ fold $]$ & 8.31 & 2.07 & 1.89 & 2.83 & 2.63 & 3.56 & 4.37 \\
\hline $\begin{array}{l}\mathrm{SD}[ \pm \mathrm{x}- \\
\text { fold] }\end{array}$ & 3.03 & 1.55 & 1.37 & 1.43 & 1.48 & 2.01 & 2.07 \\
\hline
\end{tabular}

1 Table 8 Statistical results and expression level analyses of all tested candidate reference genes during 2 skin muscle healing on account of their threshold cycle point values $(\mathrm{Ct})$ as furnished by BestKeeper 3 program. 
Table 9 (on next page)

Statistical results and expression level analysis of candidate reference genes for individuals of different weights, as based on threshold cycle point values $(\mathrm{Ct})$ provided by BestKeeper. 


\begin{tabular}{|l|c|c|c|c|c|c|c|}
\hline Factor & CYC & RPL28S & ACTB & TUBB & EFla & Ubiq & $\begin{array}{c}18 S \\
R N A\end{array}$ \\
\hline $\mathrm{N}$ & 5 & 5 & 5 & 5 & 5 & 5 & 5 \\
\hline $\mathrm{GM}[\mathrm{Ct}]$ & 24.65 & 27.6 & 20.8 & 24.22 & 22.8 & 31.02 & 26.81 \\
\hline $\mathrm{AM}[\mathrm{Ct}]$ & 24.67 & 27.72 & 20.92 & 24.37 & 23.1 & 31.09 & 27.11 \\
\hline $\mathrm{Min}[\mathrm{Ct}]$ & 23.82 & 25.18 & 18.63 & 21.82 & 19.76 & 28.45 & 21.79 \\
\hline $\mathrm{Max}[\mathrm{Ct}]$ & 25.68 & 30.97 & 24.11 & 27.85 & 27.81 & 34.42 & 32.07 \\
\hline $\mathrm{SD}[ \pm \mathrm{Ct}]$ & 0.71 & 2.54 & 2.14 & 2.65 & 3.66 & 1.88 & 3.78 \\
\hline $\mathrm{CV}[\% \mathrm{Ct}]$ & 2.88 & 9.17 & 10.23 & 10.88 & 15.83 & 6.06 & 13.94 \\
\hline $\mathrm{Min}[\mathrm{x}-\mathrm{fold}]$ & -1.78 & -5.36 & -4.52 & -5.27 & -8.27 & -5.94 & -32.48 \\
\hline $\mathrm{Max}[\mathrm{x}-$ fold $]$ & 2.04 & 10.37 & 9.9 & 12.34 & 32.22 & 10.59 & 38.4 \\
\hline $\begin{array}{l}\mathrm{SD}[ \pm \mathrm{x}- \\
\text { fold] }\end{array}$ & 1.64 & 5.83 & 4.41 & 6.28 & 12.6 & 3.69 & 13.72 \\
\hline
\end{tabular}

1 Table 9 Statistical results and expression level analyses of all tested candidate reference genes between 2 different individual weights on account of their threshold cycle point values (Ct) as furnished by 3 BestKeeper program. 